\title{
A jogszabályok és a hazai építési gyakorlat változásának hatása a lakosságvédelemre, különös tekintettel az óvóhelyi védelem lehetöségére
}

\section{The Impacts of Changing Laws and the Hungarian National Building Practice on Civil Protection with Special Attention to the Possibilities of Shelter Protection}

A kétpólusú világrend megszünésével felmerült a kérdés, hogy a lakosságvédelem szükséges-e még. További kérdés, hogy a lakosság háborúk elleni védelmét szolgáló életvédelmi létesitmények rendszere mennyire hasznositható a békeidőszaki veszélyeztető tényezők hatása ellen. A cikkben a szerzök elemzik a hazai óvóhelyek helyzetét, vizsgálják és értékelik a hazai épitési gyakorlatot, és keresik a lakosság védelmi szintjét növelö lehetöségeket a hazai épitési szabályzás tükrében.

Kulcsszavak: lakosságvédelem, óvóhelyi védelem, életvédelmi létesítmények, építési szabályok

With the end of the bipolar world order, a question has arisen: is civil protection still necessary? Another question is: to what extent can the facilities made for protecting the population against war be used against the threatening factors during periods of peace? In this article, the authors analyse the status of shelters, investigate and evaluate the national building practice and explore the opportunities of increasing the level of protection of the civilian population in the light of domestic building regulation.

Keywords: civil protection, shelter protection, life protection facilities, building rules

Nemzeti Közszolgálati Egyetem, Katonai Müszaki Doktori Iskola, doktorandusz, e-mail: ptoth@emi.hu, ORCID: 0000-0003-3516-5318

2 Nemzeti Közszolgálati Egyetem, egyetemi docens, e-mail: hornyacsek.julia@uni-nke.hu, ORCID: 0000-00022441-7383 


\section{Bevezetés}

Az elmúlt időszakban megváltozott a biztonsági környezetünk. A katasztrófák száma megnövekedett, a hatásuk kiterjedtebbé vált, így összetett kárterületek keletkeznek. A káros hatások fizikai, vegyi, biológiai és nukleáris jellegűek lehetnek, amelyek ellen a védelem rendszerének fel kell készülnie, és a lakosság „kitettségét” is csökkenteni kell. A kétpólusú világrend megszünésével a „világbéke" víziója szertefoszlott, és gyakran folynak fegyveres harcok a mikroés makrokörnyezetünkben. A háborúk, fegyveres küzdelmek nemcsak a harcoló felekre, hanem az adott terület lakosságára is nagy terheket rónak. A lakosság védelmének múlt században kialakult formái és módszerei reneszánszukat élik. A lakosságvédelem értelmezése és szakmamódszertani kérdéseinek vizsgálata ezért az elmúlt időszakban több kutatás tárgyát képezte, ${ }^{3}$ amelyek annak föként a fogalmi, rendszertani vizsgálatát célozták meg. Kevesebb azonban azoknak a vizsgálatoknak a száma, amelyek építésügyi szempontból közelítik meg a témát.

Felmerül a kérdés, hogy a lakosságvédelemnek melyek a napjainkban is alkalmazott klaszszikus formái, és mi jellemzi ezek között a lakosság óvóhelyi védelmét. További kérdés, hogy az építésügyi szabályozási eszközökkel javítható-e az óvóhelyi ellátottság. Feltételezhető, hogy a hazai szabályozásban tartalékok rejlenek, és megfelelő kiaknázásuk esetén jól szolgálhatják a lakosságvédelmi célokat. A fenti kérdések megválaszolása érdekében vizsgáljuk meg elsőként a lakosságvédelem lényegi elemeit!

\section{A lakosságvédelem értelmezése}

„A lakosságvédelem az adott területen élők szervezett védelme háború, illetve természeti és civilizációs katasztrófák, valamint egyéb jellegű rendkívüli események bekövetkeztekor. A lakosságvédelem célja, hogy az események bekövetkeztekor a lakosság életét, egészségét és anyagi javait óvja a káros és pusztító hatásoktól."4

A lakosságvédelem végigkíséri az emberiség történelmét. A korszerű lakosságvédelem kialakulása azonban az első világháború előtti időkre tehető, amikor nyilvánvalóvá vált, hogy a technika fejlődésével - elsősorban a repülők harci cselekményekben való alkalmazásával - a hátország is védtelenné vált, és a védelmi szervezeteknek, az államnak és a társadalomnak fel kell készülni a civil lakosság védelmére. A lakosság védelmének fejlődéstörténetét elemezve megállapítható, hogy a fegyveres küzdelem okozta helyzetekre való felkészülés és a káros hatások elleni védelem mellett, már az 1960-as években megjelentek a békeidőszaki veszélyeztető tényezők, kiemelten a katasztrófák. Az ezek hatásai elleni védelem új módszereket és eszközöket kívánt, de lényegét tekintve nem sokban különbözött a háborús időszaki védelemtől.

A lakosságvédelmi feladatok két csoportra oszthatók, az egyéni, illetve a kollektív (csoportos) védelemre, amelynek két formája létezik, a helyi és a távolsági védelem. Távolsági védelemnek nevezzük a kitelepítés (kiürítés), és az ezekhez kapcsolódó befogadás és visszatelepítés feladatait. Napjainkban egyre elterjedtebb a kitelepítés helyett a kimenekítési védekezési forma, amely

BONNYAI 2014; NIKODÉM 2013; KASZA 2016.

HORNYACSEK 2011, 397. 
katasztrófák esetén jobban alkalmazható. Ugyanis, ilyen esetekben a veszélyeztetett lakosságot nem kell nagy távolságra lévő befogadási helyekre szállítani. Helyi védelmi formát alapvetően az óvóhelyi védelem jelenti. A fegyveres küzdelem (háborús cselekmények) veszélyének csökkenése miatt, katasztrófák esetén, az elzárkózást mint védekezési formát alkalmazzák, amely már nem kapcsolódik kifejezetten az óvóhelyi létesítményekhez. Ezek mindegyikét a csoportos lakosságvédelmi feladatok közé soroljuk, mivel egy adott, a veszélyeztető hatással érintett területen a teljes (veszélyeztetett) lakosságra rendelik el. Az egyéni védelemnek négy területe van, a lakosság személyi védőeszközökkel, (a légzés- és bőrvédelem) egyéni dózismérő műszerekkel történő ellátása, a jódprofilaxis alkalmazása, valamint személyi mentesítési feladatok. ${ }^{5}$

A lakosságvédelmi feladatok végrehajtása össztársadalmi feladat. A klasszikus lakosságvédelmi formákat napjainkra mentő lakosságvédelemnek nevezik, a megelöző lakosságvédelem ennél sokrétűbb. Beletartozik a lakosság felkészítése, a megelőző műszaki védelem néhány feladata is. Békeidőben például fontos tevékenység a lakosságvédelem keretében a lakossági riasztórendszerek üzemeltetése, karbantartása, valamint az életvédelmi létesítmények nyilvántartása és ellenőrzése. Egy bekövetkezett katasztrófa, helyi konfliktus vagy háború során ezek az eszközök és védelmi létesítmények emberek ezreinek az életét menthetik meg, így rendkívül fontos, hogy mindig használatra kész állapotban legyenek. ${ }^{6} \mathrm{Az}$ óvóhelyi védelem egy sajátos területét képezi a lakosságvédelemnek, ${ }^{7}$ és a fejlesztésük lehetőségeiröl a szakemberek véleménye is eltérő, de abban hasonlóak, hogy a lakosságvédelmi létesítmények, köztük az óvóhelyek nem nélkülözhetők a jövőben sem.

Az épített környezet jellemzője (a lakosságvédelem szempontjából), hogy egy konkrét veszélyhelyzetre való felkészülés során nagyobb arányú, gyors átalakítása nem lehetséges. A kívánatos, még megfelelő védelmi szintet ezért az épített környezet létesítésére vonatkozó előírásokon keresztül, hosszú időtávon, fokozatosan lehetséges elérni vagy megközelíteni. A lakosság tulajdonát képező lakások elzárkózásra alkalmassá tehetők, de a tejes körü védelmet a minősített életvédelmi létesítmények kialakítása jelentheti. Figyelemreméltó, hogy az életvédelmi létesítmények kialakítása és fenntartása rövid és hosszú távon is rendkívül költséges, és gyakran más fontos feladatok erőforrásai rovására történhet. Egyes katasztrófák ellen a jól megtervezett és kialakított életvédelmi létesítmények sem nyújtanak védelmet, de a legtöbb esetben elegendőek lehetnek a kritikus időszak átvészeléséhez. ${ }^{8}$

A kutatók megállapítása szerint a meglévő életvédelmi létesítmények elégtelen kapacitása és romló müszaki állapota mellett, az épített környezetben tapasztalható további nemkívánatos folyamatok is rontják a lakosságvédelem ezen formájának lehetőségeit. Ez a tanulmány elsősorban az életvédelmi létesítmények szükségességét, a hazai építési gyakorlat, illetve a jelenlegi építési előírások hatását vizsgálja, majd áttekinti azokat az eszközöket, és módszereket, amelyekkel pozitív változások érhetők el ezen a területen. Ennek első lépése a jogszabályi háttér elemzése.

\footnotetext{
NAGY-HORNYACSEK 2014, 122

http://fovaros.katasztrofavedelem.hu/polgari-vedelmi-szolgalat (A letöltés dátuma: 2019. 05. 16.)

Fontos megemlíteni, hogy életvédelmi létesítmény az óvóhely, a szükségóvóhely, valamint az ilyen célú kettős rendeltetésü létesítmény.

8 HORNYACSEK 2011.
} 


\section{Jogszabályi keretek}

A genfi egyezményekben határozták meg a polgári védelem alaprendeltetését és feladatait. Napjainkban, hazánkban ezeket Magyarország Alaptörvénye ${ }^{9}$, a katasztrófavédelmi törvény ${ }^{10}$ és a honvédelmi törvény ${ }^{11}$ határozzák meg. ${ }^{12}$

Az életvédelmi létesítmények létesítésének, fenntartásának és békeidőszaki hasznosításának szabályait a 22/1992. (XII. 29.) KTM rendelet ${ }^{13}$ tartalmazza.

E rendelet szerint az építendő új vagy már meglévő építményeknél óvóhelyet, tekintet nélkül annak épület alatti vagy beépítetlen szabad területen lévő elhelyezésére, tervezni és kivitelezni akkor kell, ha az óvóhely megépítését a megyei (fővárosi) polgári védelmi parancsnokság javaslata alapján a megyei közgyülés elnöke, ${ }^{14}$ fővárosban a főpolgármester elrendeli, vagy az építtető önként vállalja.

Napjainkban új óvóhelyet úgy kell kialakítani, hogy az elsődleges óvóhelyi rendeltetés és a másodlagos, békés célú használat (raktározás, tárolás, garázs, kulturális, sport, kereskedelmi, szolgáltatási stb. tevékenység) lehetősége biztosított legyen. A 22/1992. (XII. 29.) KTM rendelet mellékletében megadja az óvóhelyek karbantartási feladatainak ellátásaként a tulajdonost, illetve a használót (bérlőt) terhelő és folyamatosan végzendő kötelezettségeit. Ezek lényegében a takarításon túlmenően rendszeres és dokumentált ellenőrzési és karbantartási feladatokat, az elektromos és gépészeti rendszerek hibátlan működőképességének fenntartását, a gáztömörség rendszeres ellenörzését, statikai szakvélemény készítését, felmérési tervek biztosítását jelentik.

A 234/2011. (IX. 10.) Korm. rendelette ${ }^{15}$ már hatályon kívül helyezett 60/1997. (IV. 18) Korm. rendelet ${ }^{16}$ szerint életvédelmi létesítmény: az óvóhely, a szükségóvóhely, valamint a kettős rendeltetésű létesítmény. Az óvóhely a céljának megfelelően kiépített vagy átalakítható müszaki létesítmény, amely határoló szerkezete, berendezése, felszerelése és mütárgyai révén meghatározott szintű védelmet nyújt a támadófegyverek és katasztrófák hatásai ellen. A kettős rendeltetésű létesítmény olyan építmény, amely elsősorban békeidőszaki polgári felhasználásra szolgál, de fegyveres összeütközés és katasztrófa esetén életvédelmi létesítményként használható. A szükségóvóhely olyan építmény, vagy megfelelően átalakított természeti képződmény, amely fegyveres összeütközés vagy katasztrófa idején korlátozott védelmet nyújt a hagyományos fegyverek hatásai ellen.

Az 1997. évi LXXVIII. törvény ${ }^{17}$ az épített környezet alakításáról és védelméröl rendelkezik. Többek között rögzíti az állam és a helyi önkormányzatok építésügyi feladatait, a település-

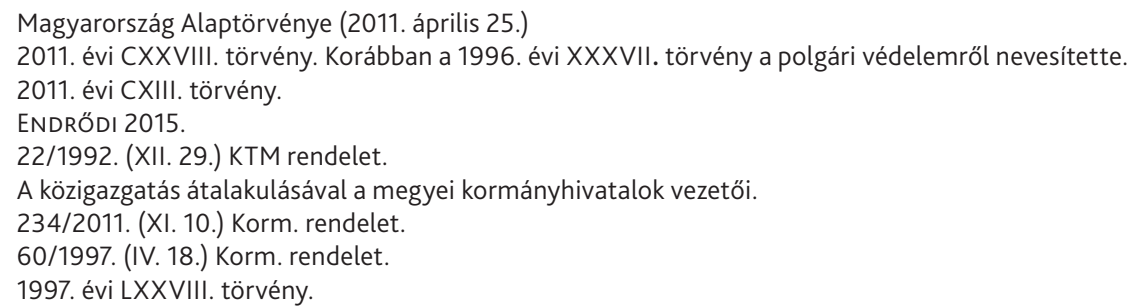


fejlesztés és településrendezés célját és követelményeit, az építményekre vonatkozó követelményeket is. Megadja a sajátos építményfajták definícióját, miszerint ezek:

„[T]öbbnyire épületnek nem minősülő, közlekedési, hírközlési, közmü- és energiaellátási, vízellátási és vízgazdálkodási, bányászati tevékenységgel és a bányászati hulladék kezelésével kapcsolatos, atomenergia alkalmazására szolgáló, valamint a honvédelmi és katonai, továbbá a nemzetbiztonsági célú, illetve rendeltetésű, sajátos technológiájú építmények, amelyek létesítésekor - az építményekre, építési tevékenységekre vonatkozó általános érvényű településrendezési és építési követelményrendszeren túlmenően - eltérő, vagy sajátos, csak arra a rendeltetésű építményre jellemző, kiegészítő követelmények megállapítására és kielégítésére van szükség." ${ }^{18}$

Az életvédelmi létesítmények tervezésére, létesítésére és müködtetésére speciális szabályzók érvényesek. A 253/1997. (XII. 20.) Korm. rendelet ${ }^{19}$ az országos településrendezési és építési követelményekről, az alábbiakat rögzíti: „Az élet, anyagi javak, kulturális értékek védelmére tervezett építményt (építményrészt, óvóhelyet) a vonatkozó külön jogszabályok és szabványok előírásainak megfelelően kell megvalósítani és fenntartani. Az életvédelmi építményt kettős rendeltetés céljára úgy kell kialakítani, hogy az a békés célú felhasználás rendeltetési feltételeinek is megfeleljen." 20

Az épületek energetikai jellemzőjével kapcsolatos tárca nélküli miniszter (továbbiakban: TNM) rendelete, a 7/2006. (V. 24.) ${ }^{21}$ pedig az európai direktíváknak megfelelően megadja a tartósan fütött épületekre vonatkozó - fokozatosan szigorodó - energetikai követelményeket és a számítási módszert. A fentiekkel szorosan összefügg az épített környezetünk tűzvédelmi biztonsága is, amelyet többek között a tűzvédelmi törvény, ${ }^{22}$ illetve az Országos Tüzvédelmi Szabályzat ${ }^{23}$ szabályoz.

Ezek a jogszabályok a kérdéskör több területét is lefedik, vannak azonban olyan területek, amelyek jogszabályi (illetve irányelvi) átgondolása időszerü. Hiányoznak például az életvédelmi létesítmények tényleges kialakításának korszerű tervezési módszerei és részletes követelményei, különös tekintettel az óvóhelyek és a kettős rendeltetésű létesítmények esetében.

\section{Az életvédelmi létesítmények létesítése és szükségessége}

A polgári lakosságot érintő, nagyarányú légibombázás mint valóságos fenyegetés, az első világháború után vált nyilvánvalóvá. Életvédelmi létesítmények tervszerủ kialakítása azonban csak a 1930-as évek közepétől vált rendszeressé, az 1935. évi XII. törvénycikk, valamint a végrehajtására vonatkozó 17.176. számú 1936. évi honvédelmi miniszteri rendelet nyomán. ${ }^{24}$

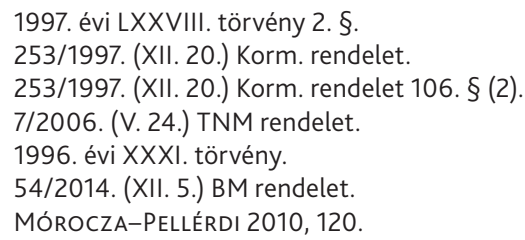


A második világháború során különösen a fővárosi lakosság ezekben a létesítményekben, illetve a rendelkezésre álló pincékben talált ideiglenes menedéket (lásd 1. és 2. ábrákat). A korabeli létesítési előírások szerint a korszakra jellemző nem éghető anyagú szerkezetekkel készült épületek jelentős sérülései mellett is volt esély arra, hogy az épület ne égjen ki, illetve hogy a szükségóvóhelyeken tartózkodók túléljék a felettük zajló harcokat. A lakosságvédelem helyi védelmi feladatait tehát több-kevesebb sikerrel az erre a célra létrehozott vagy átalakított létesítményekkel oldották meg.

A sokat szenvedett Budapesttel szemben, a faszerkezetű épületekkel épült városok sok esetben szinte teljesen megsemmisültek.

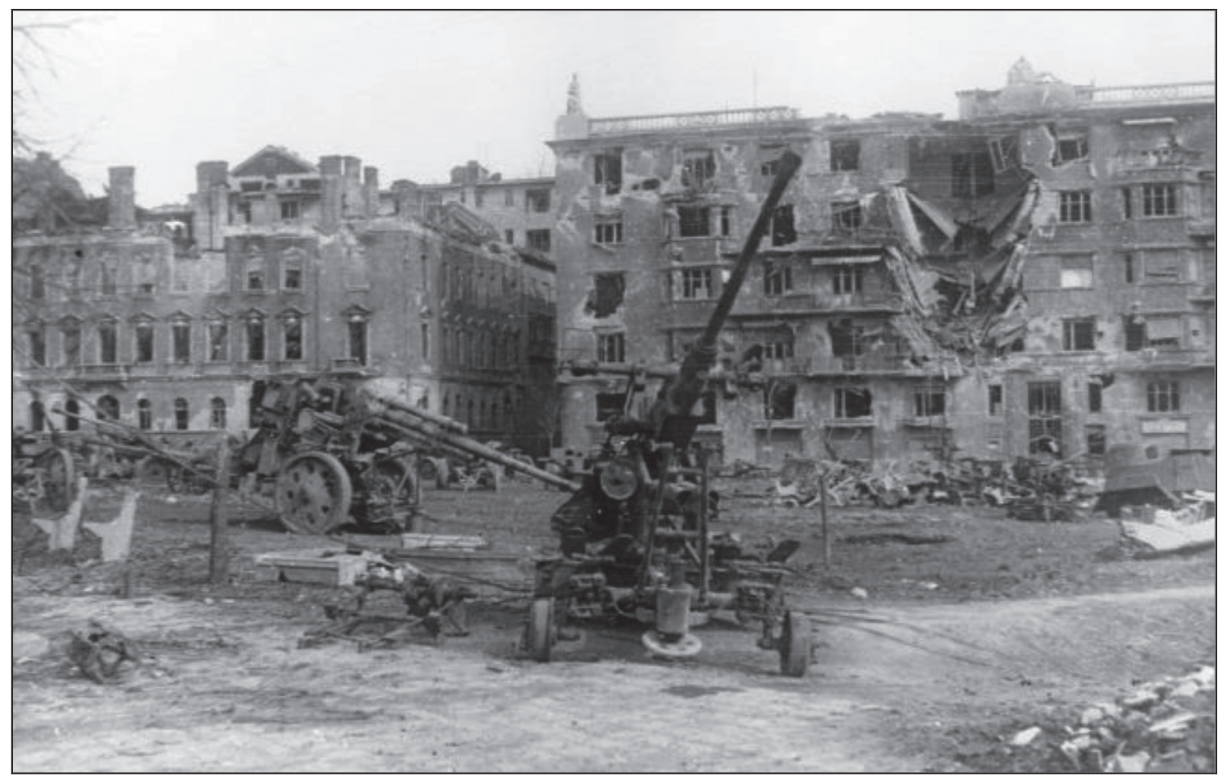

1. ábra. Házak Vérmezőn az ostrom után (jobbra az Attila út 133.)

Forrás: www.fortepan.hu/?image_id=39940 (A letöltés dátuma: 2019. 05. 16.) 


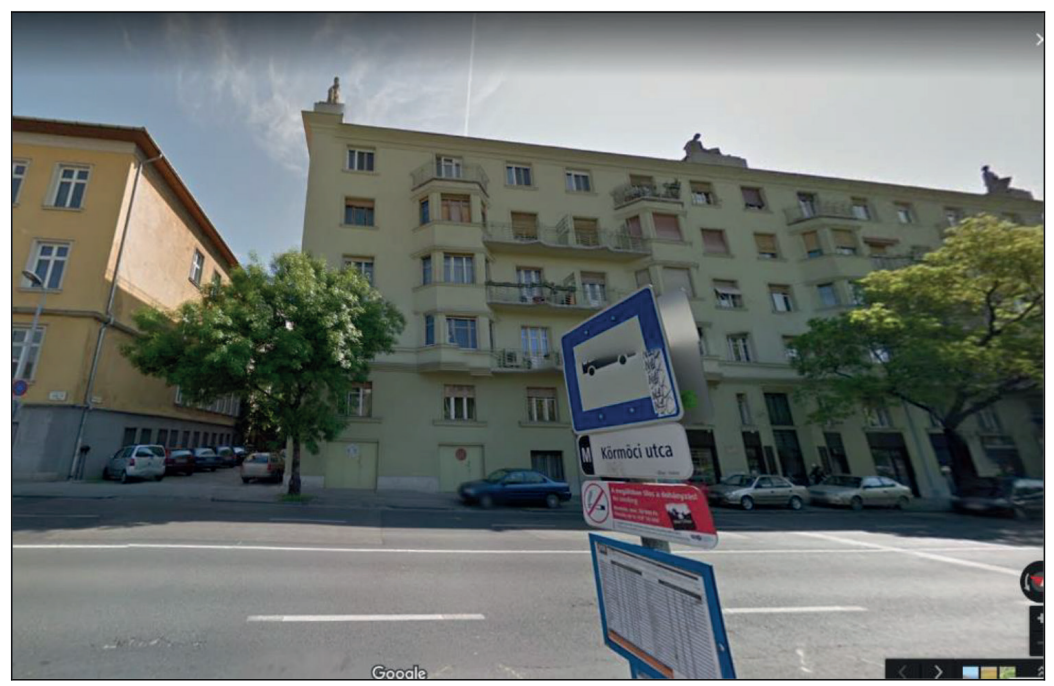

2. ábra. Az előző képen látható Attila út 133. alatti ház, amely 1956-ban is jelentősen károsodott

Forrás: Google Street View képernyőkép alapján a szerzők szerkesztése

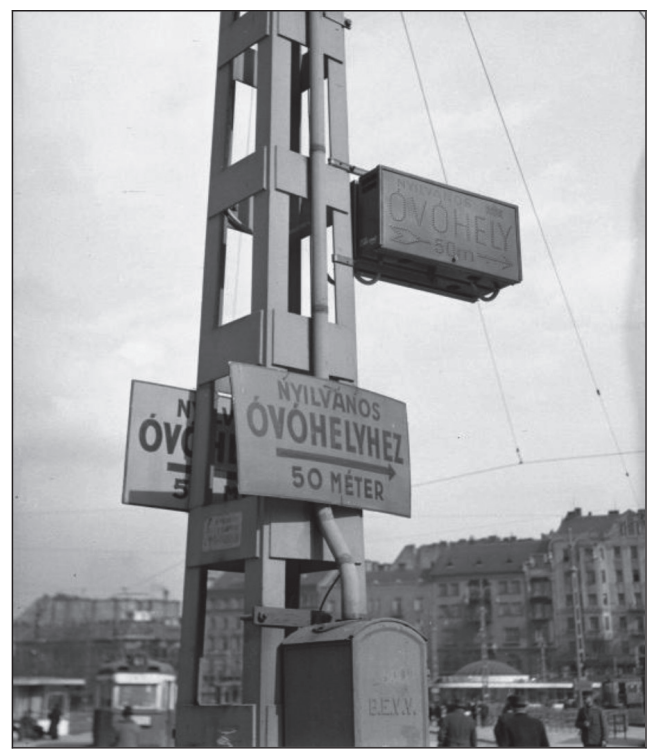

3. ábra. Tájékoztató táblák 1944-ből

Forrás: Fortepan 1944. Elérhető: www.fortepan.hu/?image_id=72663 (A letöltés dátuma: 2019. 05. 16.) 


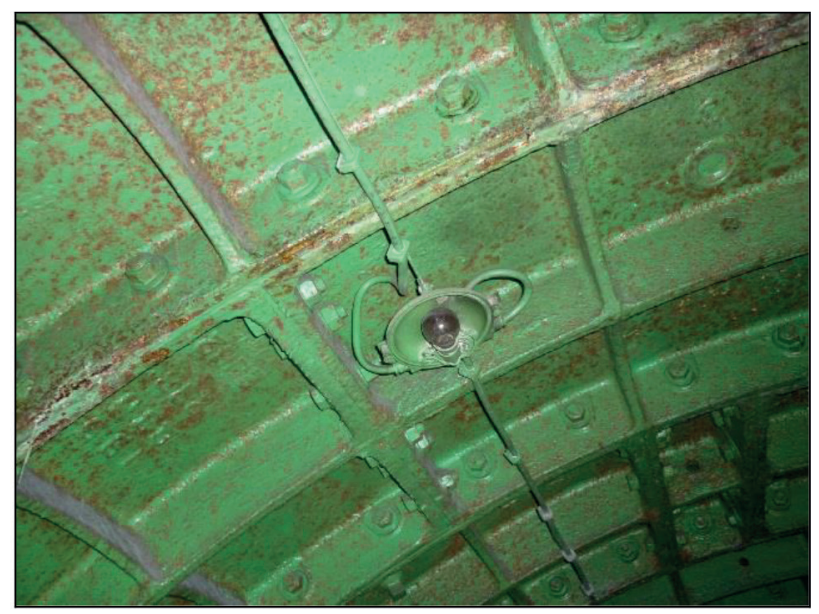

4. ábra. Az 1950-es években épült, de be nem fejezett F4-objektum fém tartóelemei

Forrás: http://indafoto.hu/fovarosiblog/image/11007713-2042009a/373127\#nagyitas (A letöltés dátuma: 2019. 05. 16.)

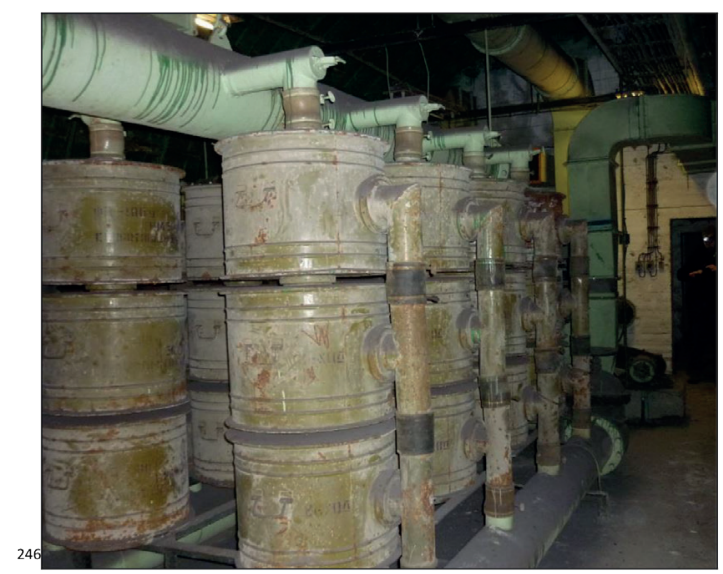

5. ábra. Az 1950-es években épült 2200 fő befogadására alkalmas lakossági óvóhely gépészeti részlete

Forrás: http://indafoto.hu/fovarosiblog/image/11007725-e62e485f/373127 (A letöltés dátuma: 2019. 05. 16.)

A második világháborút követő években is tovább folyt az életvédelmi létesítmények építése. Az RBV-kiszóródás elleni védelmet célzó, nagy óvóhelyeket egészen 1962-ig kötelezően kellett kialakítani. Ezen túlmenően az üzemi óvóhelyek kialakítása is folyt, amely a termelők védelmét biztosította (lásd 6. ábra). A főváros lakosságának védelme érdekében a metrót kettős rendeltetésüre építették. A közlekedési feladatok ellátása mellett 220 ezer fő részére biztosít teljes körü védelmet szükség esetén. Az így létesült óvóhelyeket önálló áramforrással és levegőtisztító 
berendezéssel, saját kutakkal is felszerelték (lásd 4. és 5. ábrák). A második világháború alatt és az 1950-es években a lakóházakban is voltak lakossági óvóhelyek, ezek állapota napjainkra folyamatosan romlik, elveszítik a védőképességüket, mert karbantartás hiányában a berendezések tönkremennek. ${ }^{25}$

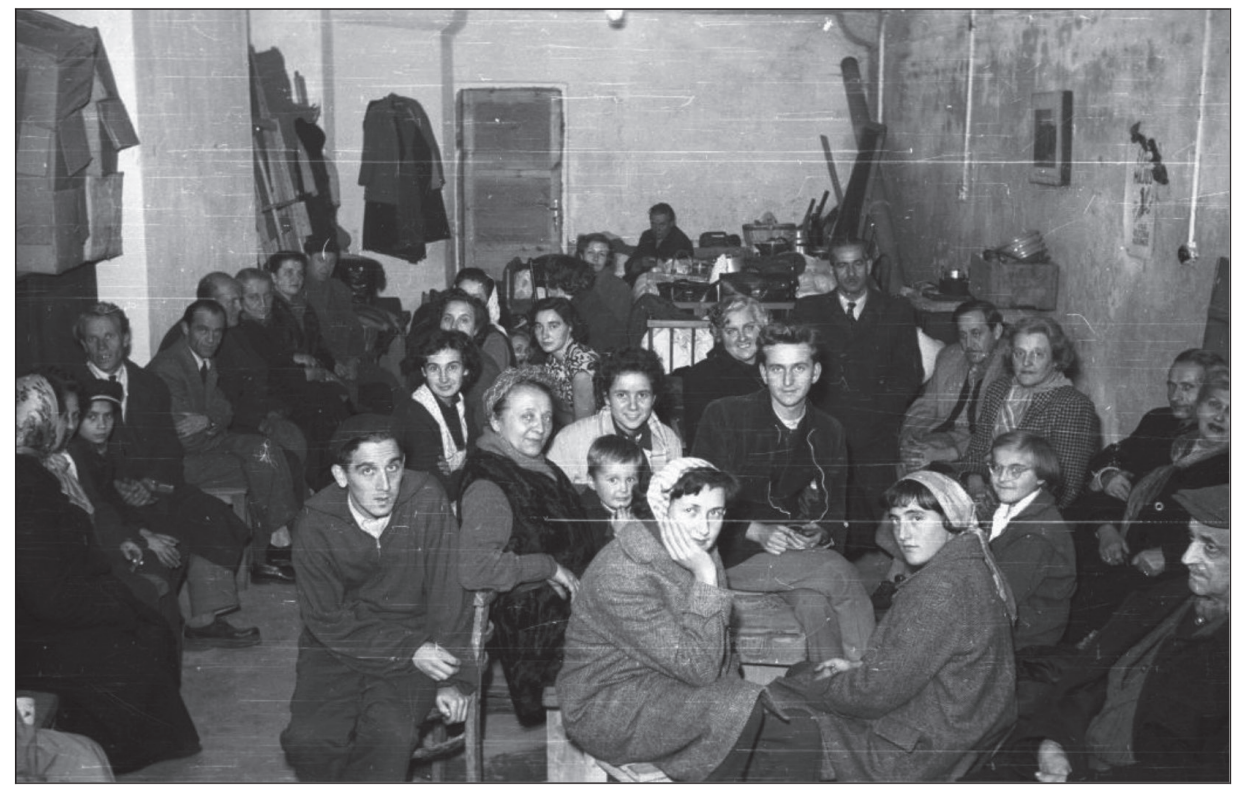

6. ábra. Budapesti óvóhely az 1956-os forradalom idején

Forrás: Fortepan 1956. Elérhető: www.fortepan.hu/?image_id=39940 (A letöltés dátuma: 2019. 05. 16.)

Az óvóhelyekkel szembeni társadalmi elvárások napjainkra megváltoztak, hiszen már nem a hidegháborús veszélyekre - például nukleáris fegyverekre, totális légitámadásokra -, hanem sokkal inkább a terrorveszélyre, ipari-civilizációs katasztrófákra kell felkészülnünk. ${ }^{26} \mathrm{~A}$ kockázatok nemcsak országhatáron belül, hanem akár kontinenseken is átívelhetnek, mint ahogy láthattuk járványok és nukleáris szennyezés esetében, de az éghajlatváltozás következményei is számos „meglepetéssel” szolgálhatnak. A korábbi védelmi elvektől eltérően, a lakosságvédelem szempontjából felmerülő - védelmi képességre vonatkozó - igény az elzárkózás követelményeire tevődött át. Mivel a hidegháborús veszély elmúltával a korábbi jogszabályi követelmények túlhaladottak, az új, a tényleges müszaki igények jelenleg a jogszabályokban vagy egyéb szabályzókban nem, vagy csak hiányosan jelentek meg. ${ }^{27}$

25 BEREK-FÖLDI 2005.

26 MÓROCZA-PELLÉRdI 2010, 122.

27 GYÖRÖK-TÓTH 2016, 80. 
A meglévő életvédelmi létesítmények száma, alapterülete egyre csökken, minthogy az óvóhelyek karbantartási feladatainak ellátása a tulajdonost, illetve a használót terheli, továbbá bárminemű használat korlátozott és körülményes, ezért azok sok munkával járó és költséges fenntartása helyett „célszerünek” látják azokat átminősíteni.

Budapesten rendelkezésre álló óvóhelyek, továbbá a metró életvédelmi létesítményei együttesen 600-700 ezer fő befogadására képesek. Ez Budapest lakosságának 40\%-a. A fővárosban kialakított óvóhelyek 10-15\%-a hasznosított (raktár, iroda, vendéglátás, kereskedelem, vendéglátás stb.). A tulajdonosi viszonyokat tekintve mintegy $40 \%$-a önkormányzati és $60 \%$-a magántulajdonú. ${ }^{28}$ Ez önmagában is problémákat vethet fel.

Állapotuk a karbantartás hiányának, valamint a szakszerűtlen átalakításoknak (például födémáttörések) köszönhetően nem megfelelő. Az elmúlt években csak néhány esetben, egyéni beruházás keretében épültek új életvédelmi létesítmények, melyek kettős rendeltetésüek. Ilyenek a mélygarázsok, amelyek alkalmasak a parkoló gépjárművek, valamint szükség esetén megfelelő átalakítással emberek befogadására is. A mélygarázsok többségének műszaki kialakítása (nyílások lezárása, szellőzés kialakítása stb.) azonban általában nem teszi alkalmassá azokat életvédelmi létesítményekként történő hasznosításra. ${ }^{29}$ Ebből adódóan, szükséges az óvóhelyek építésével, kivitelezésével és fenntartásával kapcsolatos, a vonatkozó szabályzás átgondolása, és a jelenlegi építési és védelmi követelményekhez való igazítása.

A következő fejezetben megvizsgáljuk, hogy a fentieken túl, milyen - az épített környezethez kapcsolódó - további körülmények befolyásolják a lakosságvédelmi feladatok ellátását.

\section{A jogszabályok és a hazai építési gyakorlat föbb jellemzői}

Budapest lakossága a második világháború óta megduplázódott. A technikai fejlődés nagyléptékü, és a veszélyes anyagok előállítása, felhasználása jelentősen megnövekedett. Az ipari üzemekben, logisztikai központokban nagy mennyiségben találhatók olyan anyagok, amelyek kiömlése, égése, felszabadulása jelentős veszélyt jelenthet a lakosságra. ${ }^{30} \mathrm{~A}$ lakossági és a különböző ágazatokban folyó építkezés is veszélyeket rejt magában. Az elmúlt évtizedekben az építési technológia is sokat változott, de nem mindig előnyére. Az építkezések gyors üteme több olyan veszélyt is okozhat, ami a lakosságra nézve veszélyeket rejt magában.

A hazai szabályozással és a műszaki fejlődéssel összefüggő építési gyakorlat nyomán negatív hatások is azonosíthatók, amelyek szükségessé tehetik az életvédelmi létesítmények alkalmazását, ugyanakkor nehezítik azok létesítését és a működtetést. Vizsgáljuk meg az építési gyakorlat változásait. Ezek a teljesség igénye nélkül az alábbiak:

- Az éghető műanyag habok, burkolatok, nyílászárók, kábelek stb. égése toxikus gázok felszabadulásával jár. ${ }^{31} \mathrm{Az}$ épületekben alkalmazott (és tárolt) éghető anyagok mennyisége jelentősen megnövekedett. Utólagosan hőszigetelt épületekben keletkező kis tü-

8 BEREK-FÖLDI 2005, 120.

29 BEREK-FÖLDI 2005, 120.

30 NOVÁKY 2017, 68.

31 TÓTH-КОМנÁTHY 2017. 
zek - az újonnan beépített anyagokon keresztül - többször tragikus mértékű tűzterjedést, az épület leégését okozták (például Grenfell-tűzeset Londonban). ${ }^{32}$

- Az energetikai követelmények szigorodása miatt az épületek utólagos hőszigetelése egyre vastagabb éghető (leggyakrabban EPS vagy PUR) hőszigeteléssel történik (lásd 7. ábra). Bizonyos szabályok betartása esetén még tűzfalak hőszigetelése is történhet éghető anyagokkal.

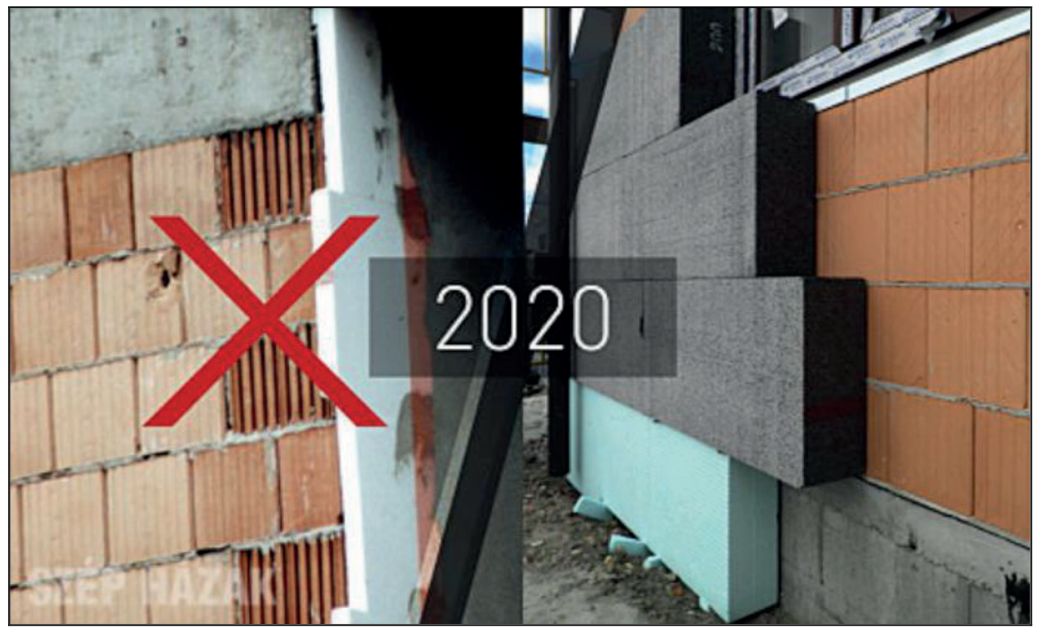

7. ábra. Reklámgrafika az alkalmazandó nagyobb hőszigetelés vastagságokról

Forrás: www.szephazak.hu/epitoipari-hirek/hoszigetelesi-vastagsagok-ma-es-holnap/1244/ (A letöltés dátuma: 2019. 05. 16.)

- Épületeink tüzvédelmét egyre nagyobb részben szolgálják aktív tüzvédelmi rendszerek: sprinklerhálózatok, vízköddel oltó berendezések stb. Védelmi szempontból figyelemreméltó, hogy ezen rendszerek lényegében müködésképtelenek a közműszolgáltatások kimaradása esetén.

- A szük utcákban a parkoló gépkocsik miatt a felvonulás lehetőségei korlátozottak, a gépkocsik önmagukban is veszélyt jelentenek (lásd 8. ábra).

- Romteherre méretezett födémekkel nem (vagy nagyon kis számban) készülnek pincék. Sok helyen egyáltalán nem készülnek pincék (takarékosságból vagy a talaj adottságai miatt).

- A meglévő pincéket rendszerint a lakók pincerekeszei töltik ki, ezek rendezetlenek.

- Új, nagy befogadóképességü épülettípusok alakultak ki (plázák, magasházak).

- Jelentősen nő a „könnyűszerkezetes”, azaz szerelt technológiával készült épületek száma. Ipari lobbi bontakozik ki, hogy többszintes, illetve középmagas épületek is készülhessenek fa tartószerkezettel. Az új OTSZ társadalmi egyeztetésre kiadott tervezete szerint:

32 То́тн 2017 
„A legfeljebb 4 szintes, NAK ${ }^{33}$ vagy AK ${ }^{34}$ mértékadó kockázati osztályba tartozó épületek tartószerkezete létesíthető az elvárt tűzállósági teljesítménynek megfelelő faanyagú szerkezetből, ha annak tűzvédelmi osztálya legalább D-s2, d0, és a szerkezeti kapcsolatok elvárt tűzállósági teljesítményét biztosítják." ${ }^{35}$ Ez lényeges könnyítés a korábbi létesítési szabályokhoz képest.

- A meglévő életvédelmi létesítmények száma csökken, elsősorban a fenntartási kötelezettség jelentős terhe miatt.

További negatívum, hogy a jellemzően kis alapterületű lakásokban a városi lakosság léte a kiszolgáló infrastruktúráktól függ, jelenleg a lakosság körében és a közműszolgáltatásban sincsenek jelentős tartalékok. Áram, víz, gáz nélkül az ellátás csak napokban mérhető. A kettős funkciójú életvédelmi létesítmények sem rendelkeznek olyan tartalékokkal, amelyek a lakosság ellátásába besegíthetnének.

A lakosság polgári védelmi ismeretekkel nem, vagy csak korlátozottan rendelkezik, önmentési készsége alacsony, a védelmi igényeket gyakran nem fogadják el, mindennapi életükkel nem egyszer akadályozzák a védelmi tevékenységet.

A fentiekből jól látható, hogy számos, lakosságvédelemmel látszólag összefüggésben nem álló körülmény kihat a lakosságvédelemre, és ezek mérlegelése szükségessé vált mind a szakemberek mind a témával foglalkozó kutatók részéről. Például Lisszabonban a tűzoltók a parkoló gépkocsik miatt nem tudták megközelíteni és lokalizálni a tüzet, így a régi fafödémes épületek teljesen kiégtek. A negyed helyreállítása 20 évet vett igénybe.

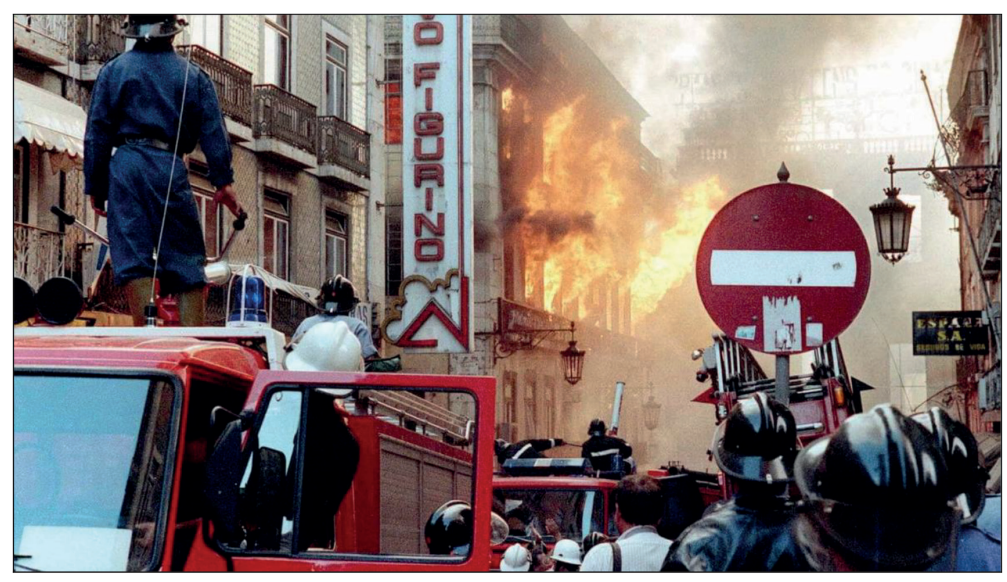

8. ábra. A lisszaboni Chiado negyed égése 1988-ban

Forrás: Exposições, livros e simulacro assinalam incêndio no Chiado 2013

33 NAK: Nagyon alacsony kockázatú.

34 AK: Alacsony kockázatú.

35 54/2014. (XII. 5.) BM rendelet 16. § (7). 
Felmerül a kérdés, hogy a műszaki fejlődés milyen lehetőségeket teremt az életvédelmi létesítmények állapotának javításához, a jó színvonal fenntartásához. Az alábbiakban ezeket a tényezőket vizsgájuk meg.

Műszaki, technológiai lehetőségek az életvédelmi létesítmények, elsősorban óvóhelyek kialakításában vagy helyettesítésében:

- Az elzárkózás jelenleg továbbra is fontos védelmi lehetőség, és már nemcsak „hagyományos" módon, hanem gyorsan felállítható/felfújható sátrak is rendelkezésre állnak erre a célra. ${ }^{36}$

- A telekommunikáció fejlődése jelentős lehetőséget ad a veszélyről (például vegyi szenynyeződésről) történő korai tájékoztatásra, az időbeni reakcióra, kimenekítésre.

- Müködő hírközlési infrastruktúra esetén a számítástechnika lehetőséget biztosíthat az egyén részére a legközelebbi óvóhely megtalálásában (telefon-cellaadatok alapján), az elzárkózott egyének hollétének nyilvántartásában, a még védelmet keresők elosztásának optimalizálásában. (A hatóságokkal és a hozzátartozókkal való kapcsolattartás igénye abba az irányba mutat, hogy az életvédelmi létesítményeket valamilyen szinten fel kell szerelni távközlési eszközökkel.)

- Korszerű műszaki berendezések jelentek meg a szürő-szellőztető rendszerek és az energiaellátás kialakításához, szinten tartásához.

- A korszerủ építészeti anyagok, technológiák, gépek, eszközök az életvédelmi létesítmények kialakításában nagy segítséget jelenthetnek.

Az épített környezetünk fejlesztése során, vélhetően a védelmi elvek és módszerek változása okán is, még napjaikban sem kap kellő hangsúlyt az óvóhelyek építése a jelenleg építőipari konjunktúra ellenére sem. Az Ipari és Technológiai Minisztérium (továbbiakban: ITM) Gazdaságstratégiáért és Szabályozásért Felelős Államtitkárságának 2019 áprilisi tájékoztatása alapján az építőipar potenciális megrendelésállománya 2018 és 2023 között kb. 25 ezer milliárd forint, ebből 15 ezer milliárdot tesznek ki az állami megrendelések. ${ }^{37}$ Ha levonjuk az ipari és infrastrukturális beruházásokat, akkor is látható, hogy kivételesen hatékony beavatkozási lehetőség áll előttünk (lásd 9. ábra) az építészet területén.

BEREK-FÖLDI 2005, 112.

37 Folytatódik a kormány építőipari technológiakorszerüsítési programja, 2019. 


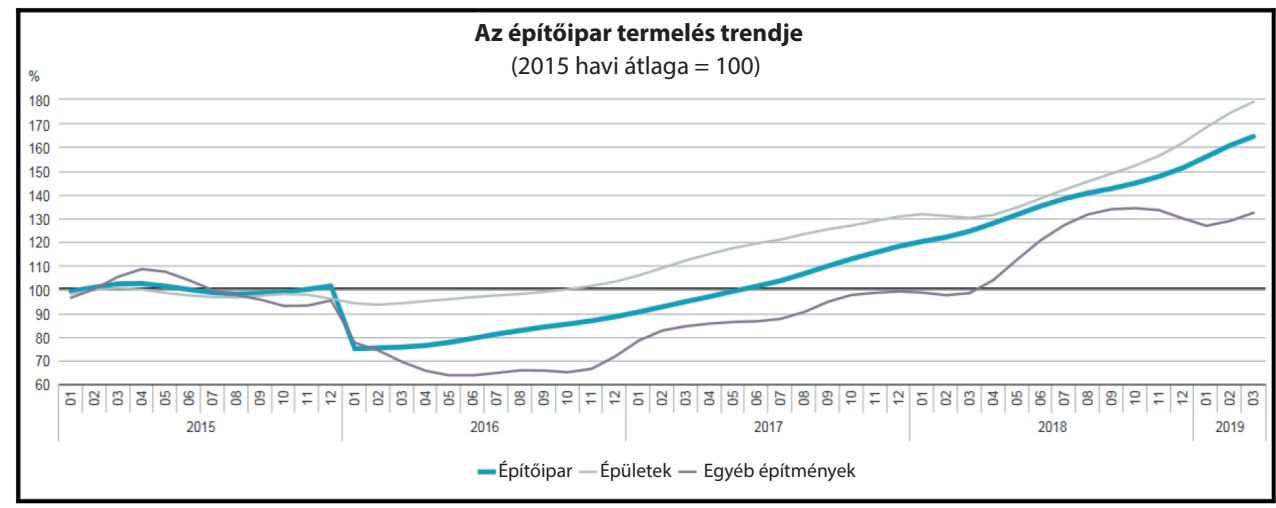

9. ábra. Az építőipari termelés trendje

Forrás: KSH 2019

A védelmi szakembereknek kezdeményezniük lehetne új építések során, ahol az szükséges, az életvédelmi létesítményeket beruházási keretből biztosítani, hiszen ezek a tartalék pénzügyi keretbe beleférhetnek.

\section{Az építésügyi szabályok és módszerek szerepe az óvóhelyi védekezés helyzetének javításában}

Az építésügyi (és hozzá kapcsolódó egyéb) szabályozással hosszú távon érdemben befolyásolni lehet az építkezéseket és az épített környezetünk jellemzőit, pozitív és negatív irányban egyaránt. Véleményünk szerint az alábbi pontokon - a szükséges hatásvizsgálatok elvégzése mellett - célirányosan be lehetne avatkozni az életvédelmi létesítmények hosszú távú fenntartása és bővítése érdekében. Az alábbiakban rendszerezzük a főbb lehetőségeket.

Az életvédelmi létesítmények létesítését és fenntartását segítő intézkedések, ösztönző tényezők:

- a védelmi igények tudatosítása az építészek, tervezők körében;

- a funkcionális helyiségek kialakítása úgy történjen, hogy az szükség esetén védelmi funkciót ellátó helyiséggé legyen átalakítható;

- az elzárkózást segítő beruházási elemek központi támogatása (például mélygarázs szükséges kiegészítő helyiségei, gépészeti berendezései, mobil felszerelések stb.);

- újépítésű lakó- és irodaépületek esetén a kettős rendeltetésű létesítmények támogatása (például áfavisszatérítésen, adókedvezményen keresztül); 
- új középületek, létesítmények esetén (bizonyos épületnagyság felett) kötelező óvóhelyek létesítése, a fenntartás támogatása (például áfavisszatérítésen vagy adókedvezmények igénybevételén keresztül); ${ }^{38}$

- a meglévő óvóhelyek felújítása, korszerüsítése vissza nem térítendő pályázati támogatással, a más funkcióra kiadott létesítmények visszaállításának biztosítása szabályzással;

- a kapacitások transzparens kezelése, például a bejáratnál kötelező tájékoztatás a meglévő létesítmények helyéről, besorolásáról, férőhelyek számáról, a támogatási igényekről;

- a felmenő szerkezetek esetén a $20 \mathrm{~cm}$ feletti homlokzati hőszigetelés vastagság felett a meglévőknél szigorúbb megkötések alkalmazása. Éghető anyagú tartószerkezetek alkalmazásának korlátozása;

- hatékony lakossági tájékoztatás (oktatás) biztosítása a közös képviselök részére a társasházakban; ${ }^{39}$

- az életvédelmi létesítmények tervezéséről szóló, visszavont MI-04-260:1992 műszaki irányelv sorozat ${ }^{40}$ korszerüsítésével olyan irányelv és típustervcsomag létrehozása, amely néhány jellemző épülettípus esetében a tervezőknek adhatna segítséget az épületek elrendezésének és szerkezeteinek meghatározásában, az életvédelmi létesítmények optimális kialakítása érdekében.

Ezeken túlmenően, hasznos lehet a felújítások esetén a védelmi funkciók javítását célzó eljárások keresése. Megjegyzendő, hogy az építészeti szabályzók módosítása során célszerü lenne az építészettel összefüggő veszélyek, és veszélyt okozó tevékenységek csökkentését célzó szabályok átgondolása.

\section{Összegzett következtetések}

A lakosság védelme napjainkra újra fókuszba került. Alapvető két területe a támogató és a mentő lakosságvédelem, amelynek egyik formája az óvóhelyi védelem. Az elmúlt időszakban az életvédelmi létesítmények, köztük az óvóhelyek állapotának javítására kevés erőforrás jutott, újak építésére elvétve került sor. Az új biztonsági kihívások megjelenésével nyilvánvaló, hogy a lakosság védelme érdekében nem nélkülözhető a meglévő óvóhelyek, és a védett vezetési pontok fenntartása. Ehhez a fentiekben azonosítottunk néhány olyan tényezőt, amely segíthetné a meglévő óvóhelyek állapotának fenntartását, javítását.

Az új életvédelmi létesítmények építését és fenntartását segítő lehetséges intézkedések és ösztönző tényezők között kiemeltük a beruházások központi támogatását, az adókedvezményeket, az építészeti formák optimalizálását, az új építési technológiák alkalmazását.

A jogszabályokat elemezve megállapítható, hogy azok a lakosság védelmének formáit, módszereit azonosítják, de az óvóhelyek kialakításának korszerü műszaki feltételeit és köve-

\footnotetext{
38 A 4-es metró beruházásánál 1-3\% többletköltséggel lehetett volna az óvóhelyi helyiségeket és gépészeti rendszereket megvalósítani. MóROCZA-PELLÉRDI 2010, 138.

39 Ez sok helyen már müködik az országban.

40 MI-1 1992, MI-2 1992, MI-3 1992, MI-4 1992, MI-5 1992, MI-6 1992.
} 
telményeit nem szabályozzák kellően. Az építésügyi jogszabályok felülvizsgálata során figyelembe kellene venni az életvédelmi létesítmények és a lakosságvédelem szempontjait és meg kell teremteni azok összhangját is.

Célszerü lenne olyan szakemberekből álló munkacsoport létrehozása, amely képes lenne a különböző építési projektek védelmi szempontból történő elemzésére, és javaslatok kidolgozására, arról, hogy a kivitelezések során a védelmi követelmények érvényesüljenek. Továbbá arról, hogy milyen ösztönző tényezőket lehetne alkalmazni a végrehajtás során.

Fel kellene mérni, hogy a lakossági építkezésekkel kapcsolatosan milyen hajlandóság mutatkozik az elzárkózást lehetővé tevő (kiszóródás elleni védelem, filtráció csökkentése) helyiségek kialakítására, és erre hogyan motiválhatók az állampolgárok.

A kutatók és a szakemberek nemzetközi példák (Svájc, Finnország Izrael, Japán stb.) elemzésével, adaptálható ötletek felkutatásával segíthetnék a témával kapcsolatos döntések meghozatalát, és a feladatok végrehajtását.

\section{Felhasznált irodalom}

BEREK Tamás - FöLDI László (2005): Néhány gondolat az óvóhelyeinkről - helyzetkép, tervek, lehetőségek. Bolyai Szemle, 14. évf. 4. sz. 107-117.

BoNNYAI Tünde (2014): A kritikus infrastruktúra védelem elemzése a lakosságfelkészités tükrében. Doktori értekezés. Budapest, Nemzeti Közszolgálati Egyetem. DOI: https://doi.org/10.17625/NKE.2015.001

ENDRŐDI István (2015): Polgári védelmi szakismeret I. NKE egyetemi jegyzet. Elérhető: http://m.ludita. uni-nke.hu/repozitorium/handle/11410/10040 (A letöltés dátuma: 2019. 05. 16.)

GYÖRÖK László - TÓTH Rudolf (2016): A lakossági óvóhelyek és a vezetési pontok alaprendeltetése, építészeti, gépészeti kialakításuk közötti különbségek. Müszaki Katonai Közlöny, 26. évf. 3. sz. 77-91.

HORNYACSEK Júlia (2011): A lakosság védelmének újszerủ értelmezése és alkalmazási lehetőségei a New Orleans-i Katrina hurrikán eseményeinek tapasztalata alapján. Müszaki Katonai Közlöny, 21. évf. 1-4. sz. 370-393.

KASZA Anett (2016): A fővárosi metró alkalmazási lehetőségei és korlátai a katasztrófák elleni védekezés területén. Doktori értekezés. Budapest, Nemzeti Közszolgálati Egyetem. DOI: https://doi. org/10.17625/NKE.2016.02

MI-1 (1992). MI-04-260-1:1992 Életvédelmi létesítmények tervezése: óvóhelyek. Általános előírások. MI-2 (1992). MI-04-260-2:1992 Életvédelmi létesítmények tervezése: óvóhelyek. Telepítési előírások. MI-3 (1992). MI-04-260-3:1992 Életvédelmi létesítmények tervezése: óvóhelyek. Építészeti előírások.

MI-4 (1992). MI-04-260-4:1992 Életvédelmi létesítmények tervezése: óvóhelyek. Tartószerkezetek, méretezési elöírások.

MI-5 (1992). MI-04-260-5:1992 Életvédelmi létesítmények tervezése: óvóhelyek. Épületgépészeti előírások.

MI-6 (1992). MI-04-260-6:1992 Életvédelmi létesítmények tervezése: óvóhelyek. A villamosenergia ellátás előírásai.

Mórocza Árpád - PeLLÉRDI Rezső (2010): Az óvóhelyi védelem aktualitásának vizsgálata, avagy a 4-es metró és Budapest. Hadmérnök, 5. évf. 1. sz. 119-140.

NAGY Sándor - HORNYACSEK Júlia (2014): Környezetvédelmi kockázatok és a lakosságvédelem összefüggései. Bolyai Szemle, 12. évf. 1. sz. 109-131.

NIKODÉM Edit (2013): A lakosság és az anyagi javak hazai védelmének újszerü értelmezése, megvalósításának követelményei, lehetséges módszerei. Doktori értekezés. Budapest, Nemzeti Közszolgálati Egyetem. DOI: https://doi.org/10.17625/NKE.2014.037 
NovÁkY Mónika (2017): Lakosságvédelmi intézkedések a veszélyes tevékenységek során, Hadmérnök, 12. évf. „KÖFOP” sz. 66-79.

TÓTH Péter - KомJÁTHY László (2017): Adding toxicity characteristics to facade fire evaluation and testing. European Science - Security, No. 2. 138-145.

То́тн Péter (2017): A Grenfell Tower tűzesetről dióhéjban. Magyar Épitőipar, 67. évf. 3-4. sz. 71-74.

\section{Internetes források}

Exposições, livros e simulacro assinalam incêndio no Chiado (2013). Elérhetö: www.noticiasaominuto.com/ cultura/99608/exposi\%C3\%A7\%C3\%B5es-livros-e-simulacro-assinalam-inc\%C3\%AAndio-nochiado (A letöltés dátuma: 2019. 05. 16.)

Folytatódik a kormány épitőipari technológiakorszerüsitési programja (2019). Elérhető: www.kormany.hu/ hu/innovacios-es-technologiai-miniszterium/gazdasagstrategiaert-es-szabalyozasert-felelos-allamtitkar/hirek/folytatodik-a-kormany-epitoipari-technologiakorszerusitesi-programja (A letöltés dátuma: 2019. 05. 16.)

Fortepan 1944. Elérhető: www.fortepan.hu/?image_id=72663 (A letöltés dátuma: 2019. 05. 16.)

Fortepan 1956. Elérhetö: www.fortepan.hu/?image_id=39940 (A letöltés dátuma: 2019. 05. 16.)

Hőszigetelési vastagságok ma és holnap. Szép Házak Online. Elérhető: www.szephazak.hu/epitoipari-hirek/ hoszigetelesi-vastagsagok-ma-es-holnap/1244/ (A letöltés dátuma: 2019. 05. 16.)

KSH gyorstájékoztató. Épitőipar, 2019. március (2019). Elérhető: www.ksh.hu/docs/hun/xftp/gyor/epi/ epi1903.html (A letöltés dátuma: 2019. 05. 16.)

Mit kell tudni az önkéntes és köteles polgári védelmi szolgálatról? Fövárosi Katasztrófavédelmi lgazgatóság. Elérhetö: http://fovaros.katasztrofavedelem.hu/polgari-vedelmi-szolgalat (A letöltés dátuma: 2019. 05. 16.)

Rákosi bunkere. Elérhető: http://indafoto.hu/fovarosiblog/image/11007713-2042009a/373127\#nagyitas (A letöltés dátuma: 2019. 05. 16.)

Rákosi bunkere. Elérhető: http://indafoto.hu/fovarosiblog/image/11007725-e62e485f/373127 (A letöltés dátuma: 2019. 05. 16.)

\section{Jogforrások}

Magyarország Alaptörvénye (2011. április 25.)

1996. évi XXXI. törvény a tűz elleni védekezésről, a müszaki mentésről és a tüzoltóságról

1997. évi LXXVIII. törvény az épített környezet alakításáról és védelméről

2011. évi CXIII. törvény a honvédelemröl és a Magyar Honvédségről, valamint a különleges jogrendben bevezethető intézkedésekről

2011. évi CXXVIII. törvény a katasztrófavédelemről és a hozzá kapcsolódó egyes törvények módosításáról 22/1992. (XII. 29.) KTM rendelet az életvédelmi létesítmények létesítéséröl, fenntartásáról és békeidőszaki hasznosításáról

234/2011. (XI. 10.) Korm. rendelet a katasztrófavédelemröl és a hozzá kapcsolódó egyes törvények módosításáról szóló 2011. évi CXXVIII. törvény végrehajtásáról

253/1997. (XII. 20.) Korm. rendelet az országos településrendezési és építési követelményekröl

54/2014. (XII. 5.) BM rendelet az Országos Tüzvédelmi Szabályzatról

60/1997. (IV. 18.) Korm. rendelet az óvóhelyi védelem, az egyéni védőeszköz-ellátás, a lakosság riasztása, valamint a kitelepítés és befogadás általános szabályairól

7/2006. (V. 24.) TNM rendelet az épületek energetikai jellemzőinek meghatározásáról 
